\title{
Biogeochemical variability during the past 3.6 million years recorded by FTIR spectroscopy in the sediment record of Lake El'gygytgyn, Far East Russian Arctic
}

\author{
C. Meyer-Jacob ${ }^{1}$, H. Vogel ${ }^{2,3}$, A. C. Gebhardt ${ }^{4}$, V. Wennrich ${ }^{2}$, M. Melles ${ }^{2}$, and P. Rosén ${ }^{1,5}$ \\ ${ }^{1}$ Department of Ecology and Environmental Science, Umeå University, 90187 Umeå, Sweden \\ ${ }^{2}$ Institute of Geology and Mineralogy, University of Cologne, Zuelpicher Str. 49a, 50674 Cologne, Germany \\ ${ }^{3}$ Institute of Geological Sciences \& Oeschger Centre for Climate Change Research, University of Bern, Baltzerstrasse $1+3$, \\ 3012 Bern, Switzerland \\ ${ }^{4}$ Alfred Wegener Institute Helmholtz Centre for Polar and Marine Research, Columbusstraße, 27515 Bremerhaven, Germany \\ ${ }^{5}$ Climate Impacts Research Centre (CIRC), Abisko Scientific Research Station, 98107 Abisko, Sweden \\ Correspondence to: C. Meyer-Jacob (carsten.meyer-jacob@emg.umu.se)
}

Received: 14 September 2012 - Published in Clim. Past Discuss.: 13 May 2013

Revised: 29 November 2013 - Accepted: 17 December 2013 - Published: 31 January 2014

\begin{abstract}
A number of studies have shown that Fourier transform infrared spectroscopy (FTIRS) can be applied to quantitatively assess lacustrine sediment constituents. In this study, we developed calibration models based on FTIRS for the quantitative determination of biogenic silica (BSi; $n=420$; gradient: $0.9-56.5 \%$ ), total organic carbon (TOC; $n=309$; gradient: $0-2.9 \%$ ), and total inorganic carbon (TIC; $n=152$; gradient: $0-0.4 \%$ ) in a $318 \mathrm{~m}$-long sediment record with a basal age of 3.6 million years from Lake El'gygytgyn, Far East Russian Arctic. The developed partial least squares (PLS) regression models yield high cross-validated (CV) $R_{\mathrm{CV}}^{2}=0.86-0.91$ and low root mean square error of crossvalidation (RMSECV) (3.1-7.0\% of the gradient for the different properties). By applying these models to 6771 samples from the entire sediment record, we obtained detailed insight into bioproductivity variations in Lake El'gygytgyn throughout the middle to late Pliocene and Quaternary. High accumulation rates of $\mathrm{BSi}$ indicate a productivity maximum during the middle Pliocene (3.6-3.3 Ma), followed by gradually decreasing rates during the late Pliocene and Quaternary. The average BSi accumulation during the middle Pliocene was $\sim 3$ times higher than maximum accumulation rates during the past 1.5 million years. The indicated progressive deterioration of environmental and climatic conditions
\end{abstract}

in the Siberian Arctic starting at ca. 3.3 Ma is consistent with the first occurrence of glacial periods and the finally complete establishment of glacial-interglacial cycles during the Quaternary.

\section{Introduction}

The understanding of past environmental changes is of particular importance to facilitate the prediction of the magnitude and the regional implications of future environmental changes, especially in view of an anthropogenically forced global warming (IPCC, 2007). Lake sediment records are valuable archives preserving these changes. Records such as those from Lake Baikal (e.g. Williams et al., 1997), Lake Malawi (e.g. Scholz et al., 2006) and Lake Biwa (e.g. Fuji, 1988) extend several million years back in time and consist of several hundred metres of sediment. However, multiproxy analyses of such long records are very time-consuming and cost-intensive. Furthermore, high-resolution sampling of these records can be restricted by the amount of sample material available for the different analyses. 
Fourier transform infrared spectroscopy (FTIRS) is a promising tool that copes with the above-mentioned problems due to its potential to analyse several components at once, simple sample pre-treatments, and the small sample size required for analysis $(0.01 \mathrm{~g})$. Because the excitation of polar bonds in molecules by IR radiation is wavenumberspecific depending on the structural and atomic composition of the molecules, it is possible to gather information about organic and minerogenic components from one single measurement. The technique has been applied to sediment to assess the concentration of silicate minerals (Sifeddine et al., 1994; Bertaux et al., 1996, 1998; Wirrmann et al., 2001) and carbonates (Mecozzi et al., 2001), as well as to characterise humic substances (Braguglia et al., 1995; Belzile et al., 1997; Calace et al., 1999, 2006; Mecozzi and Pietrantonio, 2006).

FTIRS has also successfully been applied in palaeolimnological studies to quantify biogeochemical properties such as biogenic silica, total organic carbon, total inorganic carbon, and total nitrogen (Vogel et al., 2008; Rosén et al., 2010). The developed FTIRS models of these approaches were based on site-specific and regional calibrations, respectively. Furthermore, Rosén et al. (2011) have shown that universally applicable models can be developed and applied to globally distributed lakes with considerably different settings. However, in these studies, reconstructions of selected properties by means of FTIRS have been conducted on sediment records of only a few metres' length $(<17 \mathrm{~m})$ and restricted temporal range $(<340 \mathrm{ka})$. It remains uncertain whether calibration models based on IR spectral information can be developed for and applied on several-hundred-metre-long sediment sequences extending millions of years back in time. In particular, it is important to know whether or not variations in sediment composition arising from climatic, environmental or diagenetic changes bias the robustness of IR calibrations.

In this study, FTIRS is applied to a $318 \mathrm{~m}$-long sediment record from Lake El'gygytgyn, Far East Russian Arctic $\left(67^{\circ} 30^{\prime} \mathrm{N}, 172^{\circ} 5^{\prime} \mathrm{E}\right)$ (Fig. 1), which was recovered during an ICDP (International Continental Scientific Drilling Program)-funded deep-drilling campaign in 2009 (ICDP site 5011-1; Melles et al., 2011). With its continuous formation and basal age of 3.6 million years (Melles et al., 2012; Nowaczyk et al., 2013), the record of Lake El'gygytgyn for the first time provides high-resolution insights into the climatic and environmental evolution of the Arctic during the Quaternary and late Pliocene.

Within the framework of this study, we test for the first time the applicability of IR-based calibration models for biogenic silica (BSi), total organic carbon (TOC), and total inorganic carbon (TIC) to a sediment record extending several million years back in time. Moreover, we provide new insights into the climatic and environmental evolution of the Arctic from the Pliocene to the present based upon variations in bioproductivity indicators in the sediment record of Lake El'gygytgyn.

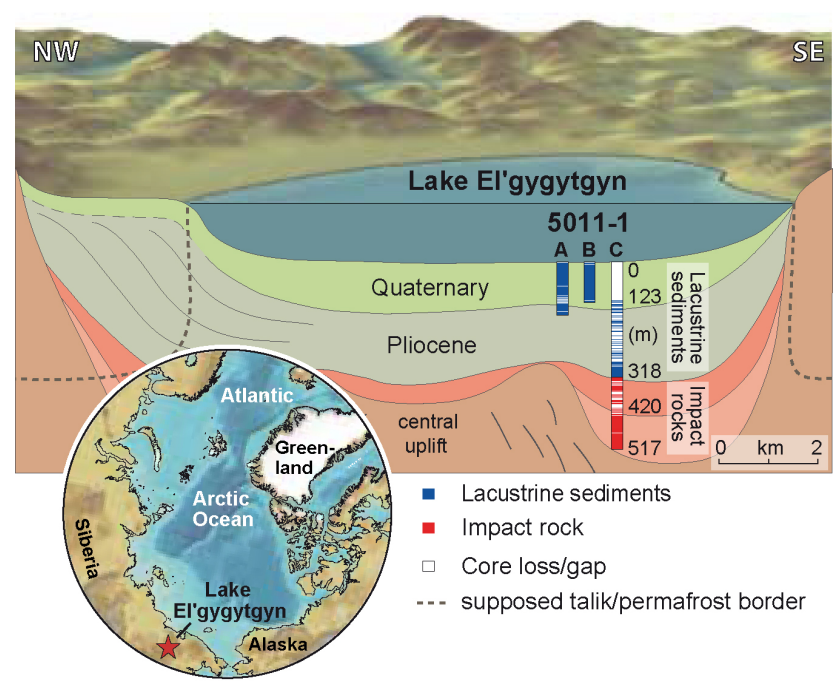

Fig. 1. Location of Lake El'gygytgyn in north-eastern Russia (inserted map) and schematic cross-section of the El'gygytgyn basin stratigraphy showing the recovery of holes A, B, and C at ICDP Site 5011-1 (modified after Melles et al., 2012).

\section{Material and methods}

\subsection{Core recovery}

Drilling operations were performed by Drilling, Observation and Sampling of the Earth's Continental Crust (DOSECC) Inc. using a GLAD-800 drilling system (Global Lake Drilling $800 \mathrm{~m}$ ) from the lake ice cover in spring 2009 (Melles et al., 2011). Drill cores from three holes (A, B, and C) along with a percussion piston core (Lz1024) at ICDP site 5011-1, which is situated in the deepest part of the lake, form a core composite that penetrates down to the underlying impact breccia at $318 \mathrm{~m}$ below lake floor (mblf) (Fig. 1).

The composite profile of site 5011-1 was continuously subsampled in $2 \mathrm{~cm}$ intervals. FTIRS measurements were performed on 6771 of these samples. For the establishment of calibration models, an additional 255 samples were taken from core catchers ( $\sim$ every $3 \mathrm{~m})$ and core cuttings ( every $1 \mathrm{~m}$ ) of the drill cores ( $n=183$ for BSi, $n=203$ for TOC and TIC), complemented by samples from 16.6 and $12.9 \mathrm{~m}$-long percussion piston cores Lz1024 at site 5011-1 $(n=204$ for BSi) (Juschus et al., 2005) and PG1351 about $2 \mathrm{~km}$ apart from site 5011-1 ( $n=83$ for $\mathrm{BSi}, n=156$ for TOC) (Melles et al., 2007).

\subsection{Analytical methods}

Conventionally measured concentrations of biogeochemical properties (BSi, TOC, and TIC) were used as reference data for the development of our calibration models. All sediment samples were freeze-dried and ground using either a swing mill (samples from drill cores of ICDP site 5011-1) or a planetary mill (samples from Lz1024 and PG1351). TC and 
TIC in samples from site 5011-1 were determined by suspension method using a DIMATOC ${ }^{\circledR} 100$ liquid analyser (Dimatec Corp.). TOC was then calculated by subtracting TIC from TC. The TOC content in samples from core PG1351 was analysed with a Metalyt-CS-1000-S (ELTRA Corp.) after sample pretreatment with HCL $(10 \%)$ at a temperature of $80^{\circ} \mathrm{C}$ to remove carbonate. Concentrations of $\mathrm{BSi}$ in all sediment cores were obtained by applying the wet chemical leaching method according to Müller and Schneider (1993).

Accumulation rates $\left(\mathrm{AR}_{X}\right)$ of $\mathrm{BSi}\left(\mathrm{AR}_{\mathrm{BSi}}\right), \mathrm{TOC}$ $\left(\mathrm{AR}_{\mathrm{TOC}}\right)$, and TIC $\left(\mathrm{AR}_{\mathrm{TIC}}\right)$ in $\mathrm{g} \mathrm{m}^{-2} \mathrm{yr}^{-1}$ were calculated according to Eq. (1):

$\mathrm{AR}_{X}=\mathrm{SR} \times \mathrm{DBD} \times \% X \times 10^{2}$,

where $\mathrm{SR}$ is the sedimentation rate in $\mathrm{cm} \mathrm{a}^{-1}$, DBD is the dry bulk density in $\mathrm{g} \mathrm{cm}^{-3}$, and $\% X$ is the concentration of the property of interest. For each sample, the composite age was calculated using linear interpolation between the tie points of the age model (Nowaczyk et al., 2013) and sedimentation rates were calculated between the geomagnetic tie points. No accumulation rates could be calculated for the first $125 \mathrm{kyr}$ of the sediment record, which originates from core Lz1024 (Melles et al., 2012), due to the lack of conventional density measurements, and for 84 samples of the remaining composite profile due to missing or erroneous density measurements.

Prior to the FTIR measurement, all samples were freezedried and ground; $0.011 \pm 0.0001 \mathrm{~g}$ sample material was then mixed with $0.5 \pm 0.0005 \mathrm{~g}$ of oven-dried spectroscopic grade potassium bromide $(\mathrm{KBr})\left(\mathrm{Uvasol}^{\circledR}\right.$, Merck Corp.), which does not influence the FTIR spectrum due to its transparency in the IR region. Afterwards the mixture was homogenised using a mortar and pestle. The low sample concentration $(2.2 \%)$ was chosen to avoid spectral distortions by very high absorbance and optical effects (Herbert et al., 1992; Griffiths and de Haseth, 2007). To gain constant measuring conditions and avoid variability caused by variations of temperature, the measurements were performed in a temperature-controlled laboratory with a constant temperature of $25 \pm 0.2{ }^{\circ} \mathrm{C}$. Samples were stored in the same room at least $5 \mathrm{~h}$ prior to the measurement. An IFS 66v/S FTIR spectrometer (Bruker Optics Inc.) equipped with a diffuse reflectance accessory (Harrick Inc.) and a Vertex 70 equipped with a HTS-XT accessory unit (Bruker Optics Inc.) were used for the analysis. Each sample was scanned 64 times at a resolution of $4 \mathrm{~cm}^{-1}$ (reciprocal centimetres) for the wavenumber range from 3750 to $450 \mathrm{~cm}^{-1}$.

\subsection{Numerical analyses}

Baseline correction and multiplicative scatter correction (MSC) were applied to normalise the recorded FTIR spectra and to remove spectral variations caused by noise (Geladi et al., 1985; Martens and Næs, 1989). We used partial least squares (PLS) regression to develop calibration models between FTIR spectral information and the corresponding conventionally measured BSi, TOC, and TIC concentrations. Conventionally measured primary sediment properties were square-root-transformed prior to analysis. All calibration models are based on the spectral range from 3750 to $450 \mathrm{~cm}^{-1}$. Previous studies have shown that models using absorption bands specific for the property of interest can exhibit similar statistical performances as models based on the entire measured IR range (Rosén et al., 2010, 2011). However, by restricting the spectral range to component-specific absorption bands, the resulting models are more sensitive to overlapping absorption bands of other sediment compounds with similar spectral features. Calibration models based on the entire measured IR range, in contrast, consider spectral regions positively and negatively correlated with the property of interest and thus are taking changes in the overall sediment composition into account.

Internal and external validations were applied to quantitatively evaluate the performance of the developed PLS models. The internal validation was performed by sevenfold cross-validation (CV), which evaluates how much of the variation in the primary data is predicted by the model (predictive power) and determines the appropriate model complexity (number of significant PLS components). In this evaluation, a calibration model based on 6/7 of the available data was applied to the remaining $1 / 7$ of the data to estimate its prediction ability. This procedure was then repeated 7 times until all samples of the data set were predicted solely based on their spectral information. The resulting cross-validated coefficient of determination $R_{\mathrm{CV}}^{2}$ and root mean square error of cross-validation (RMSECV) were used to evaluate the internal model performance. $R_{\mathrm{CV}}^{2}$ is a measure of the goodness of prediction of a model based on the predictive residual sum of squares (PRESS) (i.e. the squared difference between the predicted and observed values) and the residual sum of squares (SS) of the previous component $\left(R_{\mathrm{CV}}^{2}=1-\mathrm{PRESS} / \mathrm{SS}\right)$. A component was considered significant when $R_{\mathrm{CV}}^{2}>0$ (i.e. the component contributes to the predictive power of the model). The significance of the PLS models was tested by ANOVA (analysis of variance) of the cross-validated residuals (CV-ANOVA) (Eriksson et al., 2008) and response permutation, which estimates the degree of overfit and overprediction. Only models with a $p$ value lower than 0.001 resulting from the CV-ANOVA and valid according to the evaluation criteria of response permutations presented by Eriksson et al. (2006) were used in this study. The external validation was performed on 50 samples randomly chosen and equally distributed over the entire composite profile of ICDP site 5011-1. The coefficient of determination $\left(R^{2}\right)$ between conventionally measured and FTIRSinferred concentrations of biogeochemical properties as well as the root mean square error of prediction (RMSEP) were considered to estimate the prediction ability of the developed calibration applied to samples not included in the calibration set. 

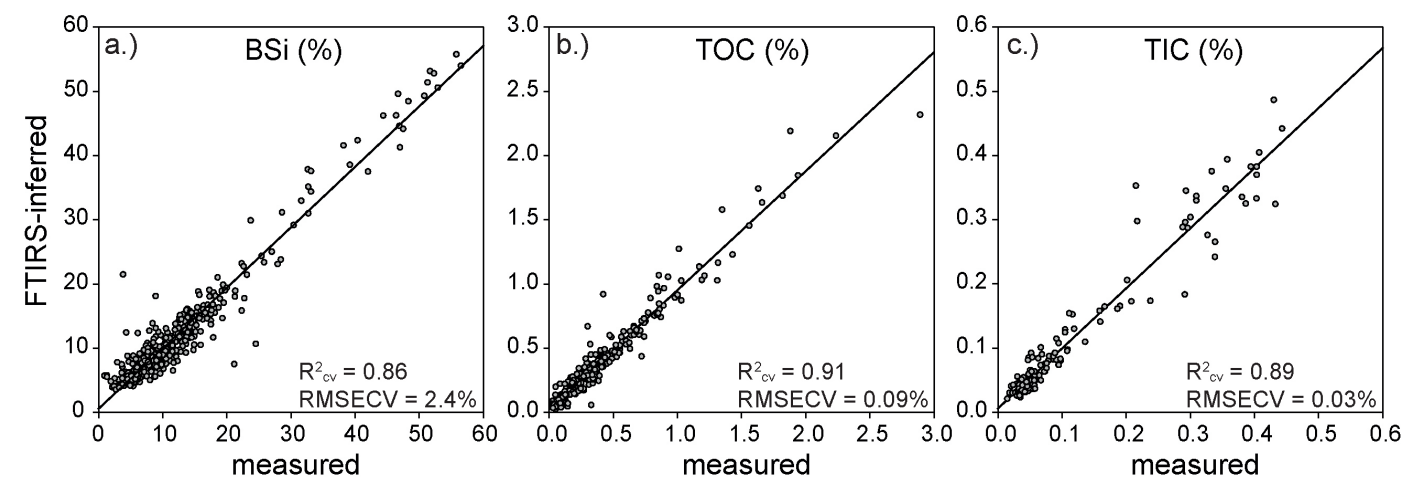

Fig. 2. Conventionally measured ( $x$ axis) versus FTIRS-inferred concentrations ( $y$ axis) of (a) biogenic silica (BSi), (b) total organic carbon (TOC), and (c) total inorganic carbon (TIC) with the cross-validated coefficient of determination $\left(R_{\mathrm{CV}}^{2}\right)$ and root mean square error of cross-validation (RMSECV) resulting from the internal validation of the developed calibration models. The calibration models are based on sediment samples from percussion piston cores PG1351 ( $n=83$ for BSi, $n=156$ for TOC) and Lz1024 ( $n=204$ for BSi) and samples distributed throughout the entire drill core composite profile of ICDP site 5011-1 ( $n=133$ for BSi, $n=153$ for TOC, $n=152$ for TIC).

We performed multivariate data analyses using SIMCAP 12.0 (Umetrics AB, Umeå, Sweden). OPUS 5.5 (Bruker Optics Inc.) was used for the visualisation of single FTIR spectra. For more information about the numerical analysis in this approach see Vogel et al. (2008) and Rosén et al. (2010).

\section{Results and discussion}

\subsection{Statistical performance of FTIRS models}

All three models - the 2-component FTIRS-BSi model, the 8-component FTIRS-TOC model, and the 8-component FTIRS-TIC model - show a strong correlation between FTIRS-inferred and conventionally measured concentrations $\left(R_{\mathrm{CV}}^{2}=0.86\right.$ for $\mathrm{BSi} ; R_{\mathrm{CV}}^{2}=0.91$ for $\mathrm{TOC} ; R_{\mathrm{CV}}^{2}=0.89$ for TIC) (Table 1, Fig. 2). Corresponding RMSECV are low: $2.4 \%$ for BSi ( $4.3 \%$ of the gradient), $0.09 \%$ for TOC (3.1\% of the gradient), and $0.03 \%$ for TIC ( $2.1 \%$ of the gradient). The external validation showed good statistical performance. The $R^{2}$ values are 0.94 for $\mathrm{BSi}$ and 0.83 for TOC, and the RMSEP values are $2.1 \%$ for BSi $(7.0 \%$ of the gradient) and $0.13 \%$ for TOC (7.9\% of the gradient), which indicate both a high prediction ability of the general trend and high prediction accuracies with respect to the absolute values of the proxy of interest. In comparison with the BSi and TOC models, the external validation of the TIC model yields a slightly poorer statistical performance $\left(R^{2}=0.86\right.$, RMSECV $=0.08 \%$ (21.1\% of the gradient)) (Table 1), indicating a high prediction ability of the general trend but a lower prediction accuracy with respect to absolute TIC values. For the TIC calibration model, one sample was excluded from the calibration set due to its high leverage on the model (TIC concentration $>3$ times higher than the concentration of the next neighbouring observation). The use of spectral regions specific for the component of interest to improve
Table 1. Statistical performance of developed calibration models for biogenic silica (BSi), total organic carbon (TOC), and total inorganic carbon (TIC) based on sediments from Lake El'gygytgyn.

\begin{tabular}{|c|c|c|c|}
\hline Statistics & $\mathrm{BSi}(\%)$ & TOC $(\%)$ & $\mathrm{TIC}(\%)$ \\
\hline \multicolumn{4}{|c|}{ Calibration set } \\
\hline PLS components & 2 & 8 & 8 \\
\hline Samples $(n)$ & 420 & 309 & 152 \\
\hline Min & 0.9 & 0.02 & 0.01 \\
\hline Max & 56.5 & 2.89 & 0.44 \\
\hline Gradient & 55.6 & 2.87 & 0.43 \\
\hline Mean & 12.1 & 0.41 & 0.11 \\
\hline Included wavenumbers $\left(\mathrm{cm}^{-1}\right)$ & $450-3750$ & $450-3750$ & $450-3750$ \\
\hline \multicolumn{4}{|c|}{ Internal validation } \\
\hline$R_{\mathrm{CV}}^{2}$ & 0.86 & 0.91 & 0.89 \\
\hline RMSECV & 2.4 & 0.09 & 0.03 \\
\hline RMSECV (\% gradient) & 4.3 & 3.1 & 7.0 \\
\hline \multicolumn{4}{|c|}{ External validation set } \\
\hline Min & 1.2 & 0.04 & 0.02 \\
\hline Max & 36.9 & 1.68 & 0.40 \\
\hline Gradient & 35.7 & 1.64 & 0.38 \\
\hline Mean & 10.1 & 0.37 & 0.09 \\
\hline \multicolumn{4}{|c|}{ External validation } \\
\hline$R^{2}$ & 0.94 & 0.83 & 0.86 \\
\hline RMSEP & 2.1 & 0.13 & 0.08 \\
\hline RMSEP (\% gradient) & 7.0 & 7.9 & 21.1 \\
\hline
\end{tabular}

the model performance as suggested by Rosén et al. (2010, 2011) improved neither the fit to the measured concentrations nor the model prediction accuracy for any of the proxies of interest. 

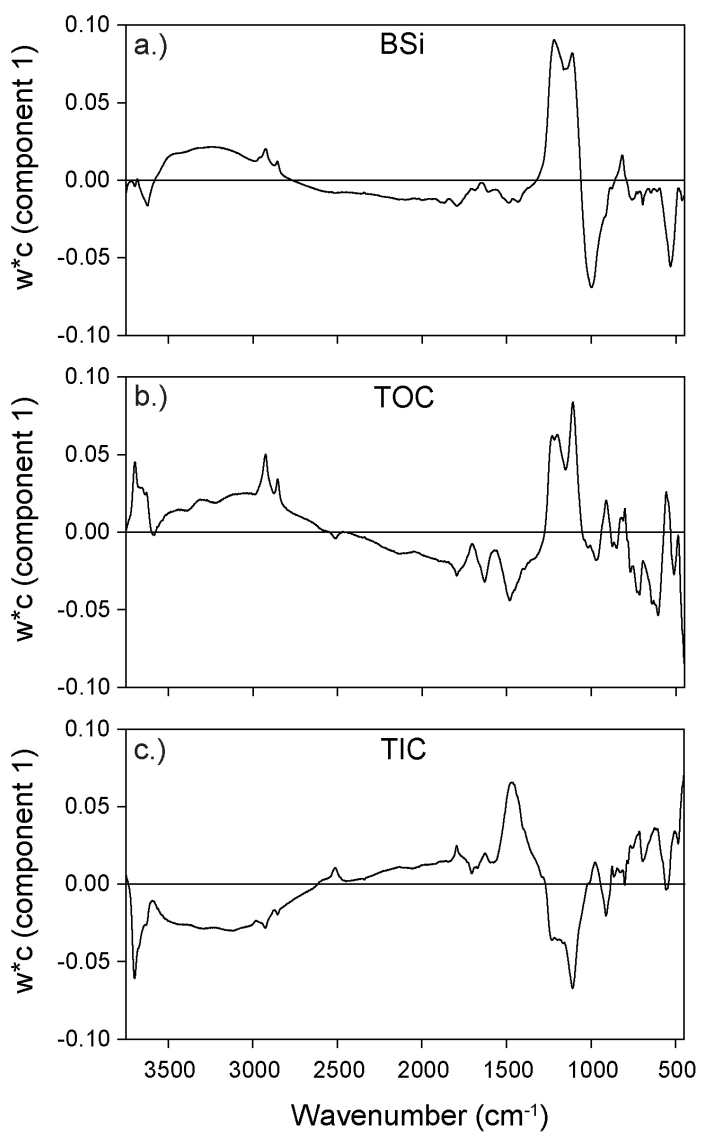

Fig. 3. Loadings of the developed FTIRS-calibration models for (a) biogenic silica (BSi), (b) total organic carbon (TOC), and (c) total inorganic carbon (TIC) showing the contribution of each wavenumber to the partial least squares (PLS) regression model. Positive values indicate wavenumbers positively correlated with the property of interest and negative values indicate wavenumbers negatively correlated with the property of interest. Loadings are expressed by weight vectors $(\boldsymbol{w} \times \boldsymbol{c})$ of the first PLS model component ( $x$ axis) and the corresponding spectral range ( $y$ axis). The calibration models are based on sediment samples from percussion piston cores PG1351 ( $n=83$ for BSi, $n=156$ for TOC) and Lz1024 ( $n=204$ for $\mathrm{BSi})$ and samples distributed throughout the entire drill core composite profile of ICDP site 5011-1 ( $n=133$ for BSi, $n=153$ for TOC, $n=152$ for TIC).

\subsection{Spectral information}

Pronounced absorption bands in the loadings of the FTIRS models can be related to known absorption bands of organic and minerogenic compounds. For the BSi model, the most important spectral regions positively correlated with the BSi concentration are situated within the ranges of 3580-2750, $1320-1060$, and $860-790 \mathrm{~cm}^{-1}$ (Fig. 3). Previous studies have shown that these regions can be attributed to absorptions caused by molecular vibrations of biogenic silica. Absorptions at around $1100 \mathrm{~cm}^{-1}$ are assigned to the asymmetric stretching vibration mode of the $\left[\mathrm{SiO}_{4}\right]$ tetrahedron,

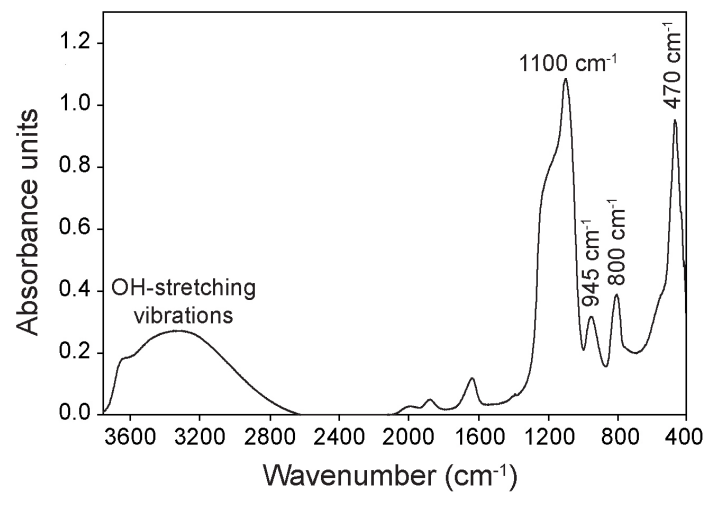

Fig. 4. FTIR spectrum of biogenic silica (BSi) from a sediment sample of Lake El'gygytgyn (core Lz1024, sample depth: $1.5 \mathrm{~m}$, sample age: $22 \mathrm{ka}$ ) that was purified according to Chapligin et al. (2012). The spectrum shows distinct absorption bands at around 1100, 945, 800 and $471 \mathrm{~cm}^{-1}$, which are associated with asymmetric Si-O-Si stretching, Si-OH molecular, symmetric Si-O-Si stretching, and Si$\mathrm{O}-\mathrm{Si}$ bending vibrations, respectively.

while the absorption band at around $800 \mathrm{~cm}^{-1}$ is caused by symmetric Si-O-Si stretching vibrations (Moenke, 1974b; Patwardhan et al., 2006). A FTIR spectrum of purified BSi from Lake El'gygytgyn sediment shows two additional absorption bands at around 471 and $945 \mathrm{~cm}^{-1}$ (Fig. 4), which are not pronounced in the loadings. The band at around $471 \mathrm{~cm}^{-1}$ is associated with the bending vibration mode of the $\left[\mathrm{SiO}_{4}\right]$ tetrahedron and the band at around $945 \mathrm{~cm}^{-1}$ is related to $\mathrm{Si}-\mathrm{OH}$ molecular vibrations (Schmidt et al., 2001; Gendron-Badou et al., 2003). Instead, these spectral regions show a negative correlation to the BSi concentration due to the fact that other silicates (e.g. feldspars, clay minerals) absorb radiation in this part of the IR spectrum as well (Farmer, 1974; Moenke, 1974b). This can result in an anticorrelation to the BSi content, because measurements of concentrations of biogeochemical properties reflect the relative proportion of biogeochemical and minerogenic compounds. The positive loading values in the spectral regions between 3580 and $2750 \mathrm{~cm}^{-1}$ can be linked to stretching vibrations of OH molecules (Moenke, 1974a), which are embedded in the molecular structure of BSi. The loadings of our BSi calibration model are consistent with loading plots for calibration models reported by Vogel et al. (2008) and Rosén et al. $(2010,2011)$.

The most important absorption band in the loadings of the TOC model is situated between 1275 and $1050 \mathrm{~cm}^{-1}$ (Fig. 3). Absorption of IR radiation in this region can be linked to known absorption bands of organic compounds. For instance, absorptions between 1265 and $1230 \mathrm{~cm}^{-1}$ are attributed to C-O stretching vibrations of ethers or carboxyl groups (Cocozza et al., 2003; Mecozzi and Pietrantonio, 2006). Absorptions at around $1125 \mathrm{~cm}^{-1}$ are due to C-O$\mathrm{C}$ stretching vibrations of complex carbohydrates, and absorptions between 1070 and $1040 \mathrm{~cm}^{-1}$ are ascribed to C-O 
stretching vibrations of carbohydrates or polysaccharides (Calace et al., 1999; Chapman et al., 2001; Cocozza et al., 2003). However, the similarity of the loading plots of TOC and BSi indicates an interdependency between both proxies. Sediment samples of Lake El'gygytgyn used for the calibration models are in general characterised by low TOC concentrations (mean: $0.41 \%$ ) and high BSi concentrations (mean: $12.1 \%$ ). It is likely that the positive loading values from 1275 to $1050 \mathrm{~cm}^{-1}$ are therefore attributed to Si-O molecular vibrations of $\mathrm{BSi}$ rather than to vibrations caused by organic matter. Positive loading values between 3000 and $2800 \mathrm{~cm}^{-1}$ with distinct peaks at 2920 and $2850 \mathrm{~cm}^{-1}$ can be attributed to stretching vibrations of $\mathrm{C}-\mathrm{H}$ molecules in $-\mathrm{CH},-\mathrm{CH}_{2}$ and $-\mathrm{CH}_{3}$ groups of aliphatic and protein chains (Chapman et al., 2001; Cocozza et al., 2003; Mecozzi and Pietrantonio, 2006). Absorption in this part of the IR spectrum is characteristic of organic matter, because an overlap with specific absorption bands of BSi can be excluded. The positive values at around $3700 \mathrm{~cm}^{-1}$ and between 3575 and $2560 \mathrm{~cm}^{-1}$ are related to absorptions caused by hydroxide groups, which are common in organic matter. However, because an influence of BSi on the calibration model for TOC is likely, it is difficult to determine how much of the absorption is caused by hydroxide contained in organic matter (direct relationship) and how much of the absorption results from hydroxide groups associated with BSi (indirect relationship).

Distinctive positive absorption peaks in the loadings of the TIC calibration model at around 2515, 1795, 875, and $715 \mathrm{~cm}^{-1}$ as well as the broad absorption band at around $1460 \mathrm{~cm}^{-1}$ (Fig. 3) correspond well with known absorption bands caused by molecular vibrations of carbonates (Huang and Kerr, 1960; Mecozzi et al., 2001). These bands match absorption bands reported for calibration models developed by Vogel et al. (2008) and Rosén et al. (2010, 2011), as well as FTIR spectra of carbonate-rich sediments (Rosén et al., 2010) corroborating the robustness of FTIRS calibration models. The negative loading values between 3730 and $2630 \mathrm{~cm}^{-1}$ and between 1270 and $1025 \mathrm{~cm}^{-1}$ can partly be explained by an indirect relationship between the occurrence of TIC and BSi. The appearance of carbonates in the analysed samples is almost exclusively restricted to the lowermost part of the sediment record and accompanied by low BSi concentrations, which result in a negative correlation of spectral regions related to molecular vibrations of $\mathrm{BSi}$ to the TIC content.

\subsection{Variability of the biogeochemical properties throughout the last 3.6 million years}

The FTIRS-inferred concentrations for $\mathrm{BSi}$ and TOC strongly vary throughout the sediment record of Lake El'gygytgyn and range between 1 and $56 \%$ for BSi and between 0 and $2.2 \%$ for TOC (Fig. $5 \mathrm{~b}$ and c). High BSi concentrations $(>25 \%)$ occur during several periods of lighter values in the global marine $\delta^{18} \mathrm{O}$ record (Lisiecki and Raymo,
2005), i.e. in sediments deposited during the marine isotope stages (MIS) KM5, KM3, G17, 101, 93, 87, 77, 57, 55, 49, $31,11 \mathrm{c}$, and 9c. Highest BSi concentrations (up to $56 \%$ ) occur in interglacial MIS 11c sediments, whereas lowest concentrations occur in the basal part of the record, which was deposited prior to 3.4 Ma. Elevated TOC concentrations $(>0.5 \%)$, in contrast, are found in sediments associated with both warm and cold periods throughout the entire sediment sequence. Particularly low TOC values are most frequently inferred for sediments from the basal part of the sediment sequence, which was formed prior to $3.5 \mathrm{Ma}$.

FTIRS-inferred concentrations of TIC vary between 0 and $5.2 \%$ (Fig. 5d). TIC predominately occurs in samples deposited in the basal part of the sediment record between 3.28 and $3.58 \mathrm{Ma}$, where it varies strongly. Due to the lack of carbonate-rich samples in the TIC calibration model, FTIRS-inferred concentrations outside of the calibration range $(0.01-0.44 \%)$ must be considered with care and are potentially over-/underestimated. Sediments formed within the first $\sim 40 \mathrm{kyr}$ after lake formation are characterised by TIC concentrations constantly above $0.2 \%$. Samples accumulated during the past $3.28 \mathrm{Myr}$ generally show variations between 0 and $0.1 \%$. Due to the RMSECV and RMSEP of $0.03 / 0.08 \%$ and the limit of detection of approximately $0.05 \%$ for the conventional analysis of TIC, upon which the FTIRS calibration model is based, most of these samples should be free of carbonate. Within this period, only four sample levels deposited during MIS 48, 38, 7d, and 6 contain detectable TIC concentrations.

Because the sedimentation rate changes significantly during the past $3.6 \mathrm{Myr}-$ from $45 \mathrm{~cm} \mathrm{kyr}^{-1}$ during the period 3.6-3.3 Ma to $4-5 \mathrm{~cm} \mathrm{kyr}^{-1}$ during the past $3.3 \mathrm{Myr}$ (Nowaczyk et al., 2013) - accumulation rates were calculated to evaluate the palaeobioproductivity and carbonate accumulation in Lake El'gygytgyn. Accumulation rates of $\mathrm{BSi}$ $\left(\mathrm{AR}_{\mathrm{BSi}}\right)$ and $\mathrm{TOC}\left(\mathrm{AR}_{\mathrm{TOC}}\right)$ show strong variations throughout the sediment record varying between 1 and 70 and between 0 and $5.2 \mathrm{~g} \mathrm{~m}^{-2} \mathrm{yr}^{-1}$, respectively (Fig. $5 \mathrm{~b}$ and c). The initial sedimentation during the first $\sim 10 \mathrm{kyr}$ is characterised by relatively high but rapidly decreasing $\mathrm{AR}_{\mathrm{BSi}}$ from 39 to $13 \mathrm{~g} \mathrm{~m}^{-2} \mathrm{yr}^{-1}$ and $\mathrm{AR}_{\mathrm{TOC}}$ from 0.7 to less than $0.1 \mathrm{~g} \mathrm{~m}^{-2} \mathrm{yr}^{-1}$. The high $\mathrm{AR}_{\mathrm{BSi}}$ at the base of the record does not necessarily reflect a high primary production by diatoms, because sediments deposited after the meteorite impact probably also contain other amorphous silicates formed by the impact (e.g. ashes, glasses). IR absorption caused by these components can have strong similarities to absorption bands of biogenic silica and therefore may lead to poor estimates by the BSi-FTIRS calibration model. The increased $\mathrm{AR}_{\mathrm{TOC}}$ is most likely an artefact of the higher uncertainty for very low FTIRS-inferred values (RMSECV $=0.09 \%$ ) and the high sedimentation rate during this period, in which FTIRSinferred TOC concentrations do not exceed $0.1 \%$. Further, it can be assumed that biological activity was strongly impaired during the initial sedimentation in the El'gygytgyn impact 


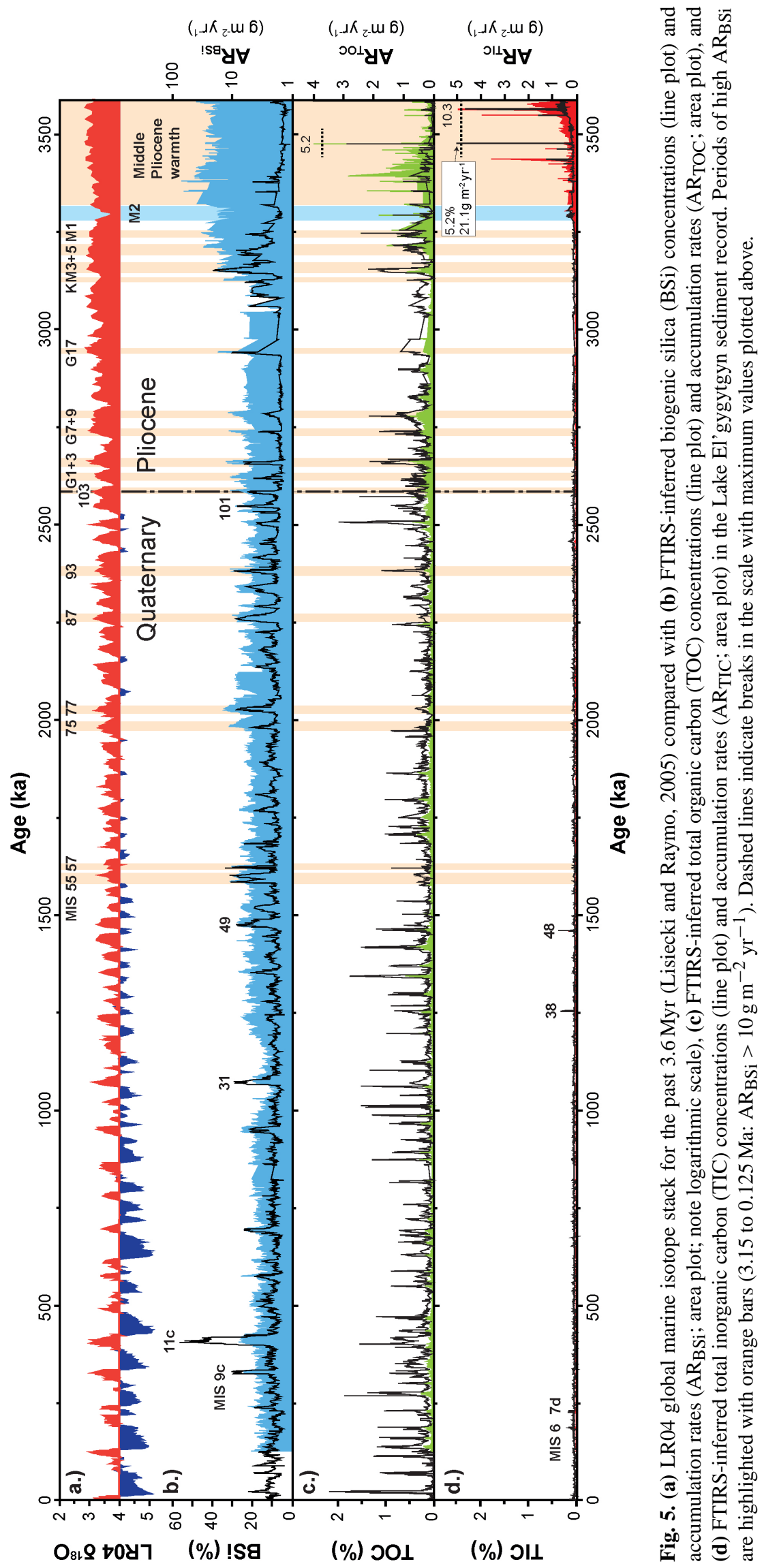


structure as a consequence of the meteorite impact. This is corroborated by the almost entire absence of microfossils in the first post-impact sediments (Brigham-Grette et al., 2013).

In Lake El'gygytgyn, aquatic bioproductivity is strongly connected to temperature variations (e.g. Melles et al., 2007). First, temperature controls the light availability via extent and duration of annual lake ice cover. Second, it controls the in-lake recycling of nutrients. Nutrients are transported from the sediment-water interface to the photic zone when the water column is fully mixed during the turnover after ice cover disintegration. And third, temperature also controls the allochthonous nutrient supply, which depends on the rate of chemical weathering, soil-forming processes, and the vegetation cover in the catchment.

The period from 3.58 to $3.32 \mathrm{Ma}$ represents the longest period of constantly high $\mathrm{AR}_{\mathrm{BSi}}$ at Lake El'gygytgyn, with an average rate of $24 \mathrm{~g} \mathrm{~m}^{-2} \mathrm{yr}^{-1}$, indicating favourable conditions for bioproductivity (Fig. 5b). This period of high BSi deposition partly coincides with the early Pliocene warm period $(\sim 5-3 \mathrm{Ma})$, which was characterised by $\sim 2-$ $3{ }^{\circ} \mathrm{C}$ higher global surface temperatures compared to today (Haywood and Valdes, 2004; Brierley et al., 2009), an atmospheric $p \mathrm{CO}_{2}$ of $\sim 400$ ppmv (Pagani et al., 2010; Seki et al., 2010), reduced high-latitude ice sheet extents (Hill et al., 2010; McKay et al., 2012), and a global sea level 10-40 m above present (Raymo et al., 2011). Pollen-based temperature and precipitation reconstructions from the El'gygytgyn sediment record suggest regional temperatures of $7-8^{\circ} \mathrm{C}$ and precipitation values of around $400 \mathrm{~mm} \mathrm{yr}^{-1}$ higher than today for the period between 3.6 and 3.4 Ma (Brigham-Grette et al., 2013). Furthermore, this period at Lake El'gygytgyn is characterised by a significantly larger size of the dominant planktonic diatom (Pliocaenicus sp.) compared to any other interval in the sediment record, indicating increased nutrient availability and reduced seasonal ice cover (Brigham-Grette et al., 2013).

The productivity maximum at Lake El'gygytgyn is followed by a period of lower $\mathrm{AR}_{\mathrm{BSi}}$ from 3.32 to $3.28 \mathrm{Ma}$ (MIS M2), in which the average accumulation rate drops to $12 \mathrm{~g} \mathrm{~m}^{-2} \mathrm{yr}^{-1}$. A reduced bioproductivity during this period is consistent with cooler and dryer conditions inferred from the pollen record (Brigham-Grette et al., 2013). Marine sediment records suggest a coincident cooling of sea surface temperatures in the North Atlantic between $2-3{ }^{\circ} \mathrm{C}$ (De Schepper et al., 2009) and $6^{\circ} \mathrm{C}$ (Lawrence et al., 2009) and a sea level lowstand of $\sim 65 \mathrm{~m}$ below present (Dwyer and Chandler,

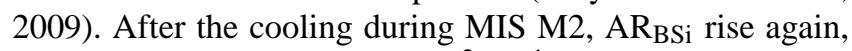
reaching rates of up to $32 \mathrm{~g} \mathrm{~m}^{-2} \mathrm{yr}^{-1}$ during MIS M1, but subsequently decrease to rates mostly below $10 \mathrm{~g} \mathrm{~m}^{-2} \mathrm{yr}^{-1}$ in the period between 3.28 and 3.15 Ma. This decline is interrupted by two $\mathrm{AR}_{\mathrm{BSi}}$ maxima during MIS KM5 and KM3. These isotope stages as well as MIS M1 are associated with global sea level highstands (Dwyer and Chandler, 2009). The stepwise decrease in BSi deposition and thus the deterioration of environmental conditions for in-lake bioproduction from 3.32 Ma onwards is consistent with the onset of ice sheet expansion and cooling of coastal waters in Antarctica at about 3.3 Ma (McKay et al., 2012) and with decreasing $p \mathrm{CO}_{2}$ concentrations from 3.2 Ma on (Seki et al., 2010). The fluctuations in bioproductivity between 3.6 and $3.15 \mathrm{Ma}$ as deduced from $\mathrm{AR}_{\mathrm{BSi}}$ variations are well supported by variations in TOC accumulation, with peaks in $\mathrm{AR}_{\mathrm{TOC}}$ being largely correlated with periods of lighter values in the global marine $\delta^{18} \mathrm{O}$ record and increased $\mathrm{AR}_{\mathrm{BSi}}$ (Fig. 5c).

Compared to the bioproductivity maximum during the middle Pliocene and the high but decreasing $\mathrm{AR}_{\mathrm{BSi}}$ from 3.3 Ma onwards, accumulation rates of $\mathrm{BSi}$ are considerably lower during the late Pliocene and Quaternary (Fig. 5b). From 3.15 to $1.8 \mathrm{Ma}$, the average BSi accumulation rate amounts to $5.2 \mathrm{~g} \mathrm{~m}^{-2} \mathrm{yr}^{-1}$, but with peak values $\left(\mathrm{AR}_{\mathrm{BSi}}>10 \mathrm{~g} \mathrm{~m}^{-2} \mathrm{yr}^{-1}\right)$ occurring during the warm phases MIS G17, G9, G7, G3, G1, 103, 93, 87, 77, and 75. According to pollen-based temperature and precipitation reconstruction from Lake El'gygytgyn, the period 3.26 to $2.2 \mathrm{Ma}$ can be described as a protracted period of warm and moist conditions, approximately $3-6^{\circ} \mathrm{C}$ warmer and between 100 and $200 \mathrm{~mm}$ wetter than today (Melles et al., 2012; BrighamGrette et al., 2013). However, a gradual climatic deterioration is indicated by the increased occurrence of summers cooler than today from $2.5 \mathrm{Ma}$ and the gradually increasing frequency of glacial periods between 2.3 and $1.8 \mathrm{Ma}$.

$\mathrm{BSi}$ fluxes decrease further during the period from 1.8 to $0.125 \mathrm{Ma}$, when glacial-interglacial cycles are well expressed at Lake El'gygytgyn (Melles et al., 2012), suggesting a further long-term deterioration of environmental and climatic conditions for bioproductivity in the Siberian Arctic. This period is characterised by average $\mathrm{AR}_{\mathrm{BSi}}$ of $3.9 \mathrm{~g} \mathrm{~m}^{-2} \mathrm{yr}^{-1}$, and $\mathrm{AR}_{\mathrm{BSi}}>10 \mathrm{~g} \mathrm{~m}^{-2} \mathrm{yr}^{-1}$ only occur during MIS 57 and 55. From 1.5 Ma onwards, maximum $\mathrm{AR}_{\mathrm{BSi}}$ no longer exceed $8.5 \mathrm{~g} \mathrm{~m}^{-2} \mathrm{yr}^{-1}$. Interestingly, accumulation rates during the so-called "super interglacials" MIS 31 and $11 \mathrm{c}$ do not exhibit outstanding high $\mathrm{AR}_{\mathrm{BSi}}$, despite pollen-based climate reconstructions suggesting conditions up to $4-5{ }^{\circ} \mathrm{C}$ warmer and $\sim 300 \mathrm{~mm}$ wetter compared to present (Melles et al., 2012). Although the BSi concentrations during MIS $11 \mathrm{c}$ are by far the highest in the entire Lake El'gygytgyn sediment record, $\mathrm{AR}_{\mathrm{BSi}}$ are not comparatively elevated during this period. This may be best explained by an intensified catchment stabilisation, e.g. by a dense vegetation cover and soil formation, which has considerably reduced the supply of mineral matter from the catchment. A detailed multi-proxy study focusing on MIS 11c at Lake El'gygytgyn, provided by Vogel et al. (2013), shows similarities to the last deglaciation and interhemispheric climate connectivity during this period. However, the processes leading to the exceptional composition of MIS 11c sediments compared to any other period of the sediment record remain ambiguous.

During the past $3.15 \mathrm{Myr}$, elevated $\mathrm{AR}_{\mathrm{TOC}}$ are increasingly associated with heavier values in the global marine $\delta^{18} \mathrm{O}$ record (Fig. 5c), reflecting the increase in frequency 
of glacial periods during the Quaternary. In the Lake El'gygytgyn sediments, the TOC amount is strongly connected to the duration of lake ice cover (Melles et al., 2007). During glacial times with perennial ice cover, which requires mean annual temperatures of at least $3.3( \pm 0.9)^{\circ} \mathrm{C}$ below today (Nolan, 2013), mixing of the water column is hampered, leading to oxygen-depleted bottom waters and enhanced organic matter preservation in the sediment. During warmer periods, in contrast, the annual ice cover disintegration allows for wind- and density-driven mixing that leads to an oxygenation of the bottom water and enhanced organic matter decomposition. However, elevated $\mathrm{AR}_{\mathrm{TOC}}$ also occur during particularly warm interglacials, when the bioproductivity is very high and the organic matter decomposition incomplete (Melles et al., 2007, 2012). This is particularly the case for MIS G9, G7, and G3.

The accumulation rates of TIC $\left(\mathrm{AR}_{\mathrm{TIC}}\right)$ confirm the pattern already shown by the TIC concentrations with high carbonate values at the core base, a successive decrease to carbonate absence by $3.28 \mathrm{Ma}$, and four single occurrences during MIS 48, 38, 7d, and 6 (Fig. 5d). The significant concentration and accumulation of carbonate in the basal sediments might be connected to the origin of the lake depression by the meteorite impact $3.58 \pm 0.04 \mathrm{Ma}$ (Layer, 2000). The impact may have induced hydrothermal activity, which is common after impact events, where the melted/heated target material acting as a heat source interacts with near-surface $\mathrm{H}_{2} \mathrm{O}$ (Naumov, 2002). Amongst others, calcite can be precipitated in such a hydrothermal system (Osinski et al., 2005). This process is also indicated by the existence of secondary calcite in the underlaying impact breccia and bedrock (Raschke et al., 2013). Therefore, we assume that carbonate deposition during the early stage of Lake El'gygytgyn is related to erosion and dissolution of secondary/hydrothermal carbonates in the catchment and redeposition and reprecipitation in the lake.

The four glacials/stadials during the Quaternary with exceptional carbonate deposition (MIS 48, 38,7d, and 6) show very low BSi (means: 5.1-6.4\%) and medium TOC concentrations (means: $0.39-0.78 \%$ ). According to the sediment classification after Melles et al. (2007, 2012), these periods represent peak cold glacial conditions with permanent lake ice cover and anoxic bottom waters. Sediments of this climate mode are further characterised by elevated but low total sulphur concentrations due to sulphate reduction and by enhanced bacterial methanogenesis (Melles et al., 2007). Under anoxic/reducing conditions, carbonate phases like rhodochrosite $\left(\mathrm{MnCO}_{3}\right)$ and siderite $\left(\mathrm{FeCO}_{3}\right)$ can form as a result of microbially mediated organic matter oxidation and $\mathrm{Mn}$ and $\mathrm{Fe}$ oxyhydroxide reduction. The occurrence of siderite is restricted to non-sulphidic, methanic environments, whereas rhodochrosite occurs in both sulphidic and non-sulphidic environments (Glasby and Schulz, 1999, and references therein). Due to the low sedimentation rate and the overall low organic content in the Lake
El'gygytgyn sediment record, formation of these carbonates types appears to be exceptional. Further studies are required to confirm the carbonate type and to better understand the processes leading to carbonate accumulation during these specific glacials/stadials.

\section{Conclusions}

The results of our study for the first time demonstrate that robust FTIRS calibration models can be developed for the quantitative assessment of biogeochemical properties in very long $(>300 \mathrm{~m})$ sediment records extending several million years back in time. The developed models relating FTIR spectral information to conventional measurements for TOC, TIC and BSi show a good statistical performance for the 3.6 Myr-old sediment record of Lake El'gygytgyn.

By applying these models in higher resolution to the sediment sequence, we obtained a detailed reconstruction of variations in the aquatic bioproductivity in Lake El'gygytgyn, which is primarily triggered by climate changes. Our results show a productivity maximum during the middle Pliocene (3.6-3.3 Ma) indicated by very high accumulation rates of $\mathrm{BSi}$. After a stepwise drop of in-lake bioproductivity between 3.3 and $3.15 \mathrm{Ma}, \mathrm{AR}_{\mathrm{BSi}}$ gradually decreased during the past 3.15 Myr. The indicated progressive deterioration of environmental and climatic conditions in the Siberian Arctic coincides with the increased occurrence of glacial periods culminating in the full establishment of high-amplitude glacialinterglacial cycles during the Quaternary. Compared to average $\mathrm{BSi}$ accumulation rates during the middle Pliocene, maximum $\mathrm{BSi}$ accumulation rates are 1.4 and 2.8 times lower during the period $3.15-1.5 \mathrm{Ma}$ and $1.5-0.125 \mathrm{Ma}$, respectively. The agreement of the $\mathrm{AR}_{\mathrm{BSi}}$ with general climate patterns highlights the climate sensitivity of BSi at Lake El'gygytgyn. Furthermore, the occurrence of carbonates, predominately in basal sediments of the record (3.63.3 Ma), could be shown by means of FTIRS.

Our study demonstrates that FTIRS is a fast and costeffective analytical alternative to conventional methods for the quantitative estimation of biogeochemical properties such as BSi, TOC, or TIC - that allows the determination of several proxies from one single measurement. Its successful application to a record extending several million years back in time corroborates the potential of the technique for other deep-drilling projects dealing with long lacustrine or marine sediment successions.

Acknowledgements. The El'gygytgyn Drilling Project was funded by the International Continental Scientific Drilling Program (ICDP), the US National Science Foundation (NSF), the German Federal Ministry of Education and Research (BMBF), Alfred Wegener Institute (AWI) and GeoForschungsZentrum Potsdam (GFZ), the Russian Academy of Sciences Far East Branch (RAS FEB), the Russian Foundation of Basic Research (RFBR), and the 
Austrian Federal Ministry of Science and Research (BMWF). The Russian GLAD 800 drilling system was developed and operated by DOSECC Inc., and LacCore at the University of Minnesota handled core curation. We would like to thank Per Persson (Umeå University) for providing access to FTIR equipment, Nicole Mantke (University of Cologne) for laboratory assistance, and Annika Holmgren, Carin Olofsson, and Cecilia Rydberg (Umeå University) for FTIRS assistance. Funding for the FTIRS research was provided by the Swedish Research Council (VR), FORMAS, and the Kempe Foundation.

Edited by: P. Minyuk

\section{References}

Belzile, N., Joly, H. A., and Li, H.: Characterization of humic substances extracted from Canadian lake sediments, Can. J. Chem., 75, 14-27, 1997.

Bertaux, J., Ledru, M. P., Soubiès, F., and Sondag, F.: The use of quantitative mineralogy linked to palynological studies in paleoenvironmental reconstruction: the case study of the "Lagoa Campestre" lake, salitre, Minas Gerais, Brazil, C. R. Acad. Sci. Paris, 323, 65-71, 1996.

Bertaux, J., Fröhlich, F., and Ildefonse, P.: Multicomponent analysis of FTIR spectra: quantification of amorphous and crystallized mineral phases in synthetic and natural sediments, J. Sediment. Res., 68, 440-447, 1998.

Braguglia, C. M., Campanella, L., Petronio, B. M., and Scerbo, R.: Sedimentary humic acids in the continental margin of the Ross Sea (Antarctica), Int. J. Environ. Anal. Chem., 60, 61-70, 1995.

Brierley, C. M., Fedorov, A. V., Liu, Z., Herbert, T. D., Lawrence, K. T., and LaRiviere, J. P.: Greatly expanded tropical warm pool and weakened Hadley circulation in the early Pliocene, Science, 323, 1714-1718, 2009.

Brigham-Grette, J., Melles, M., Minyuk, P., Andreev, A., Tarasov, P., DeConto, R., Koenig, S., Nowaczyk, N., Wennrich, V., Rosén, P., Haltia-Hovi, E., Cook, T., Gebhardt, C., Meyer-Jacob, C., Snyder, J., and Herzschuh, U.: Pliocene Warmth, Polar Amplification, and Stepped Pleistocene Cooling recorded in NE Arctic Russia, Science, 340, 1421-1427, 2013.

Calace, N., Capolei, M., Lucchese, M., and Petronio, B. M.: The structural composition of humic compounds as indicator of organic carbon sources, Talanta, 49, 277-284, 1999.

Calace, N., Cardellicchio, N., Petronio, B. M., Pietrantonio, M., and Pietroletti, M.: Sedimentary humic substances in the Northern Adriatic Sea (Mediterranean Sea), Mar. Environ. Res., 61, 4058, 2006.

Chapligin, B., Meyer, H., Bryan, A., Snyder, J., and Kemnitz, H.: Assessment of purification and contamination correction methods for analysing the oxygen isotope composition from biogenic silica, Chem. Geol., 300-301, 185-199, 2012.

Chapman, S. J., Campbell, C. D., Fraser, A. R., and Puri, G.: FTIR spectroscopy of peat in and bordering Scots pine woodland: relationship with chemical and biological properties, Soil Biol. Biochem., 33, 1193-1200, 2001.

Cocozza, C., D’Orazio, V., Miano, T. M., and Shotyk, W.: Characterization of solid and aqueous phases of a peat bog profile using molecular fluorescence spectroscopy, ESR and FT-IR, and comparison with physical properties, Org. Geochem., 34, 49-60, 2003.

De Schepper, S., Head, M. J., and Groeneveld, J.: North Atlantic Current variability through marine isotope stage M2 (circa 3.3 Ma) during the mid-Pliocene, Paleoceanography, 24, PA4206, doi:10.1029/2008PA001725, 2009.

Dwyer, G. S. and Chandler, M. A.: Mid-Pliocene sea level and continental ice volume based on coupled benthic $\mathrm{Mg} / \mathrm{Ca}$ paleotemperatures and oxygen isotopes, Philos. T. Roy. Soc. A, 367, 157$168,2009$.

Eriksson, L., Johansson, E., Kettaneh-Wold, N., Trygg, J., Wikström, C., and Wold, S.: Multi- and megavariate data analysis Part I: Basic principles and applications, 2nd Edn., Umetrics AB, Umeå, Sweden, 2006.

Eriksson, L., Trygg, J., and Wold, S.: CV-ANOVA for significance testing of PLS and OPLS ${ }^{\circledR}$ models, J. Chemometr., 22, 594-600, 2008.

Farmer, V. C.: The layer silicates, in: The Infrared Spectra of Minerals, edited by: Farmer, V. C., Mineralogical Society Monograph 4, Adlard \& Son, Dorking, Surrey, 331-363, 1974.

Fuji, N.: Palaeovegetation and palaeoclimate changes around Lake Biwa, Japan during the last ca. 3 million years, Quaternary Sci. Rev., 7, 21-28, 1988.

Geladi, P., MacDougall, D., and Martens, H.: Linearization and scatter-correction for near-infrared reflectance spectra of meat, Appl. Spectrosc., 39, 491-500, 1985.

Gendron-Badou, A., Coradin, T., Maquet, J., Fröhlich, F., and Livage, J.: Spectroscopic characterization of biogenic silica, J. Non-Cryst. Solids, 316, 331-337, 2003.

Glasby, G. P. and Schultz, H. D.: $E_{\mathrm{H}}, \mathrm{pH}$ diagrams for Mn, Fe, Co, $\mathrm{Ni}, \mathrm{Cu}$ and $\mathrm{As}$ under seawater conditions: applications of two new types of $E_{\mathrm{H}}, \mathrm{pH}$ diagrams to the study of specific problems in marine geochemistry, Aquatic Geochem., 5, 227-248, 1999.

Griffiths, P. R. and de Haseth, J. A.: Fourier transform infrared spectroscopy, Wiley, New York, 2007.

Haywood, A. M. and Vales, P. J.: Modelling Pliocene warmth: contribution of atmosphere, oceans and cryosphere, Earth Planet. Sc. Lett., 218, 363-377, 2004.

Herbert, T. D., Brian, A. D., and Burnett, C.: Precise major component determination in deep-sea sediments using Fourier transform infrared spectroscopy, Geochim. Cosmochim. Acta, 56, 1759-1763, 1992.

Hill, D. J., Dolan, A. M., Haywood, A. M., Hunter, S. J., and Stoll, D. K.: Sensitivity of the Greenland Ice Sheet to Pliocene sea surface temperatures, Stratigraphy, 7, 111-121, 2010.

Huang, C. K. and Kerr, P. F.: Infrared study of the carbonate minerals, Am. Mineral., 45, 311-324, 1960.

IPCC: Climate change 2007: The physical science basis, in: Contribution of Working Group I to the Fourth Assessment Report of the Intergovernmental Panel on Climate Change, edited by: Solomon, S., Qin, D., Manning, M., Chen, Z., Marquis, M., Averyt, K. B., Tignor, M., and Miller, H. L., Cambridge University Press, Cambridge and New York, 2007.

Juschus, O., Wennrich, V., Quart, S., Minyuk, P., Melles, M., Gebhardt, C., and Niessen, F.: New long record Lz1024, in: The expedition El'gygytgyn lake 2003 (Siberian Arctic), edited by: Melles, M., Minyuk, P., Brigham-Grette, J., and Juschus, O., Reports Polar Mar. Res., 509, 110-113, 2005. 
Lawrence, K. T., Herbert, T. D., Brown, C. M., Raymo, M. E., and Haywood, A. M.: High-amplitude variations in North Atlantic sea surface temperature during the early Pliocene warm period, Paleoceanography, 24, PA2218, doi:10.1029/2008PA001669, 2009.

Layer, P. W.: Argon-40/argon-39 age of the El'gygytgyn impact event, Chukotk, Russia, Meteorit. Planet. Sci., 35, 591-599, 2000.

Lisiecki, L. E. and Raymo, M. E.: A Pliocene-Pleistocene stack of 57 globally distributed benthic $\delta^{18} \mathrm{O}$ records, Paleoceanography, 20, PA1003, doi:10.1029/2004PA001071, 2005.

Martens, H. and Næs, T.: Multivariate Calibration, John Wiley \& Sons, Chichester, New York, Brisbane, Toronto, Singapore, 1989.

McKay, R., Naish, T., Carter, L., Riesselman, C., Dunbar, R., Sjunneskog, C., Winter, D., Sangiorgi, F., Warren, C., Pagani, M., Schouten, S., Willmott, V., Levy, R., DeConto, R., and Powell, R. D.: Antarctic and Southern Ocean influences on late Pliocene global cooling, P. Natl. Acad. Sci. USA, 109, 6423-6428, 2012.

Mecozzi, M. and Pietrantonio, E.: Carbohydrates proteins and lipids in fulvic and humic acids of sediments and its relationships with mucilanginous aggregates in the Italian seas, Mar. Chem., 101, 27-39, 2006.

Mecozzi, M., Pietrantonio, E., Amici, M., and Romanelli, G.: Determination of carbonate in marine solid samples by FTIR-ATR spectroscopy, Analyst, 126, 144-146, 2001.

Melles, M., Brigham-Grette, J., Glushkova, O. Y., Minyuk, P. S., Nowacyk, N. R., and Hubberten, H.-W.: Sedimentary geochemistry of core PG1351 from Lake El'gygytgyn - a sensitive record of climate variability in the East Siberian Arctic during the past three glacial-interglacial cycles, J. Paleolimnol., 37, 89-104, 2007.

Melles, M., Brigham-Grette, J., Minyuk, P., Koeberl, C., Andreev, A., Cook, T., Federov, G., Gebhardt, C., Haltia-Hovi, E., Kukkonen, M., Nowaczyk, N., Schwamborn, G., Wennrich, V., and the El'gygytgyn Scientific Party: the El'gygytgyn Scientific Drilling Project - conquering Arctic challenges through continental drilling, Sci. Drill., 11, 29-40, 2011.

Melles, M., Brigham-Grette, J., Minyuk, P. S., Nowaczyk, N. R., Wennrich, V., DeConto, R. M., Anderson, A., Andreev, A. A., Coletti, A., Cook, T. L., Haltia-Hovi, E., Kukkonen, M., Lozhkin, A. V., Rosén, P., Tarasov, P., Vogel, H., and Wagner, B.: 2.8 million years of Arctic climate change from Lake El'gygytgyn, NE Russia, Science, 337, 315-320, 2012.

Moenke, H. H. W.: Vibrational spectra and the crystal-chemical classification of minerals, in: The Infrared Spectra of Minerals, edited by: Farmer, V. C., Mineralogical Society Monograph 4, Adlard \& Son, Dorking, Surrey, 111-118, 1974a.

Moenke, H. H. W.: Silica, the three-dimensional silicates, borosilicates and beryllium silicates, in: The Infrared Spectra of Minerals, edited by: Farmer, V. C., Mineralogical Society Monograph 4, Adlard \& Son, Dorking, Surrey, 365-382, 1974 b.

Müller, P. J. and Schneider, J.: An automated leaching method for the determination of opal in sediments and particulate matter, Deep-Sea Res., 40, 424-444, 1993.

Naumov, M. V.: Impact-generated hydrothermal systems: data from Popigai, Kara, and Puchezh-Katunki impact structures, in: Impacts in Precambrian Shields, edited by: Plado, J. and Pesonen, L. J., Springer-Verlag, Berlin, 117-171, 2002.
Nolan, M.: Quantitative and qualitative constraints on hind-casting the formation of multiyear lake-ice covers at Lake El'gygytgyn, Clim. Past, 9, 1253-1269, doi:10.5194/cp-9-1253-2013, 2013.

Nowaczyk, N. R., Haltia, E. M., Ulbricht, D., Wennrich, V., Sauerbrey, M. A., Rosén, P., Vogel, H., Francke, A., MeyerJacob, C., Andreev, A. A., and Lozhkin, A. V.: Chronology of Lake El'gygytgyn sediments - a combined magnetostratigraphic, palaeoclimatic and orbital tuning study based on multi-parameter analyses, Clim. Past, 9, 2413-2432, 2013,

http://www.clim-past.net/9/2413/2013/.

Osinski, G. R., Lee, P., Parnell, J., Spray, J. G., and Baron, M.: A case study of impact-induced hydrothermal activity: the Haughton impact structure, Devon Island, Canadian High Arctic, Meteorit. Planet. Sci., 40, 1859-1877, 2005.

Pagani, M., Liu, Z., LaRiviere, J., and Ravelo, A. C.: High earthsystem climate sensitivity determined from Pliocene carbon dioxide concentrations, Nat. Geosci., 3, 27-30, 2010.

Patwardhan, S. V., Maheshwari, R., Mukherjee, N., and Clarson, S. J.: Conformation and assembly of polypeptide scaffolds in templating the synthesis of silica: an example of a polylysine macromolecular "switch", Biomacromolecules, 7, 491-497, 2006.

Raschke, U., Schmitt, R. T., and Reimold, W. U.: Petrography and geochemistry of impactites and volcanic bedrock in the ICDP drill core D1c from Lake El'gygytgyn, NE Russia, Meteorit. Planet. Sci., 48, 1251-1286, 2013.

Raymo, M. E., Mitrovica, J. X., O’Leary, M. J., DeConto, R. M., and Hearty, P. J.: Departures from eustasy in Pliocene sea-level records, Nat. Geosci., 4, 328-332, 2011.

Rosén, P., Vogel, H., Cunningham, L., Reuss, N., Conley, D. J., and Persson, P.: Fourier transform infrared spectroscopy, a new method for rapid determination of total organic and inorganic and biogenic silica concentration in lake sediments, J. Paleolimnol., 43, 247-259, 2010.

Rosén, P., Vogel, H., Cunningham, L., Hahn, A., Hausmann, S., Pienitz, R., Zolitschka, B., Wagner, B., and Persson, P.: Universally applicable model for the quantitative determination of lake sediment composition using Fourier transform infrared spectroscopy, Environ. Sci. Technol., 45, 8858-8865, 2011.

Schmidt, M., Botz, R., Rickert, D., Bohrmann, G., Hall, S. R., and Mann, S.: Oxygen isotope of marine diatoms and relations to opal-A maturation, Geochim. Cosmochim. Acta, 65, 201-211, 2001.

Scholz, C. A., Cohen, A. S., Johnson, T. C., King, J. W., and Moran, K.: The 2005 Lake Malawi drilling project, Sci. Drill., 2, 17-19, 2006.

Seki, O., Foster, G. L., Schmidt, D. N., Mackensen, A., Kawamura, K., and Pancost, R. D.: Alkenone and boron-based Pliocene $p \mathrm{CO}_{2}$ records, Earth Planet. Sc. Lett., 292, 201-211, 2010.

Sifeddine, A., Fröhlich, F., Fournier, M., Martin, L., Servant, M., Soubiès, F., Turcq, B., Suguio, K., and Volkmer-Ribeiro, C.: La sedimentation lacustre indicateur de changements des paléoenvironnements au cours des 30000 dernières années (Carajasm Amazonie, Brésil), C. R. Acad. Sci. Paris, 318, 1645-1652, 1994.

Vogel, H., Rosén, P., Wagner, B., Melles, M., and Persson, P.: Fourier transform infrared spectroscopy, a new cost-effective tool for qualitative analysis of biogeochemical properties in long sediment records, J. Paleolimnol., 40, 689-702, 2008. 
Vogel, H., Meyer-Jacob, C., Melles, M., Brigham-Grette, J., Andreev, A. A., Wennrich, V., Tarasov, P. E., and Rosén, P.: Detailed insight into Arctic climatic variability during MIS 11c at Lake El'gygytgyn, NE Russia, Clim. Past, 9, 1467-1479, doi:10.5194/cp-9-1467-2013, 2013.

Williams, D. F., Peck, J., Karabanov, E. B., Prokopenko, A. A., Kravchinsky, V., King, J., and Kuzmin, M. I.: Lake Baikal record of continental climate response to orbital insolation during the past 5 million years, Science, 278, 1114-1117, 1997.

Wirrmann, D., Bertaux, J., and Kossoni, A.: Late Holocene paleoclimatic changes in Western Central Africa inferred from mineral abundance in dated sediments from Lake Ossa (Southwest Cameroon), Quaternary Res., 56, 275-287, 2001. 